\title{
The Effects of Public Investments and Accessibility to National Markets on the Demand for Distance Education
}

\author{
Kamu Yatırımlarının ve Ulusal Pazarlara Erişimin \\ Uzaktan Eğitim Talebine Etkileri
}

\author{
Assoc. Prof. Dr. Bahar Berberoğlu - Assoc. Prof. Dr. Rabia Ece Omay \\ Prof. Dr. C. Necat Berberoğlu - Res. Asst. Çağlar Karaduman
}

\begin{abstract}
Başvuru Tarihi: 17.02.2017
Kabul Tarihi: 06.06.2017
\end{abstract}

\begin{abstract}
Public investments are directed to the social and economic areas. The state must carry public investments and services to every corner of the country, such as transportation, sewage, energy, education and health care by considering social stability and meeting human needs. Otherwise, unrest and disobedience may start to be experienced in the under developed regions and migration begins towards the developed areas in which the infrastructure services are completed. The regional insufficiency in public investments creates political, social and economic imbalances and instability. Differences in physical, social and geographical conditions between the regions of a country are generally based on the problems such as, the uneven distribution of the population, the differences in agricultural production and dissemination of industrial activities only in certain regions. The regions which are close to the national market are generally known to be more developed due to the use of market advantage. Transportation infrastructure and access to the national market affect the economic performance of the regions. In all provinces of Turkey, Anadolu University Open Education System has an important place by providing open and distance learning services. In this study, the relationship between
\end{abstract}

the demands of open education system is investigated both with public investments and national market accessibility index respectively. For this purpose, different regression models were established and these models were evaluated statistically. In conclusion, the presence of linear positive correlation was determined.

Keywords: Public Investments, National Market Accessibility Index, Open Education System, Regression Analysis

\section{Öz}

Kamu, sosyal ve iktisadi olarak her iki yönde yatırım yapar. Kamu yatırımları sosyal dengeleri gözetmek ve beşeri ihtiyaçları karşılamak için yol, kanalizasyon, enerji, eğitim ve sağlik gibi hizmetleri ülkenin her köşesine götürmesi gerekmektedir. Aksi halde bölgelerde huzursuzluk ve itaatsizlik yaşanır ve böyle bölgelerden altyapısı tamamlanmış bölgelere göç başlar. Kamu yatırımlarındaki bölgesel yetersizlikler siyasi, sosyal ve ekonomik olarak dengesizlikler ve istikrarsızliklar yaratır. Bir ülke içerisinde fiziki, beşeri ve coğrafi şartlar, nüfusun dengesiz dă̆ılımı, tarımsal üretimdeki farklı-

\footnotetext{
Assoc. Prof. Dr. Bahar Berberoğlu, Anadolu University Open Education Faculty, bdirem@anadolu.edu.tr Assoc. Prof. Dr. Rabia Ece Omay, receomay@gmail.com

Prof. Dr. C. Necat Berberoğlu, Faculty of Economics and Administrative Sciences, nberbero@anadolu.edu.tr Res. Asst. Çağlar Karaduman, Anadolu University Faculty of Economics, caglarkaraduman@anadolu.edu.tr
} 
liklar ya da sanayi faaliyetlerinin belli bölgelere yayllması gibi nedenlerle iç ticaret hacmi bölgeler arası farklara yol açabilir. Ulusal pazara yakın olan bölgelerin uzak olan bölgelere göre pazar avantajını kullanmaları nedeniyle daha gelişmiş olacağı bilinir. Ulaştırma ve erişim altyapısı bölgelerin ekonomik performanslarım etkilemektedir. Türkiye'de 81 ilde Anadolu Üniversitesi Açıköğretim Sistemi, açık ve uzaktan öğretim ile ülke çapinda önemli bir yere sahiptir. Bu çalışmada Anadolu Üniversitesi Açıöğretim Sistemi kamu yatırımları ve ulusal pazara erişilebilirlik arasındaki ilişkiler açısından incelenmiş, bu amaçla farklı regresyon modelleri kurulmuş ve bu modeller istatistiksel açıdan değerlendirilmiştir. Kurulan regresyon modellerinde kamu yatırımları ve ulusal pazara erişilebilirlik ile Açıöğretim Sistemine gelen yeni kayıtlar, ek yerleștirmeler, dikey geçişler, lisans tamamlamalar, ikinci üniversite seçimi ve kayıt yeniletme değişkenleri arasındaki ilişkiler modellenmiştir. Sonuç olarak, Açıöğretim Sistemine yönelen talep ile söz konusu değişkenler arasında pozitif yönde doğrusal ilişkilerin varlğg tespit edilmiştir.

Anahtar Kelimeler: Kamu yatırmlar, Ulusal Pazara Erişilebilirlik Endeksi, Açı̋öğretim Sistemi, Regresyon Analizi

\section{Introduction}

Investment can be generally defined as a risk taken in order to gain a higher profit in the future by renouncing the current profit of the capital. The benefit can be categorized into two as social and individual. Public investments are made for the purpose of increasing social benefit (Kalem, 2015). Public investments are one of the expenditure items addressed within the capital intensive public expenditures. Public investment expenditures have a special significance due to their contributions to the economic and socioeconomic growth because, whereas, on the one hand, public investment projects meet the country's need for infrastructure, on the other hand, they contribute to the production capacity and, also, increase the productivity of the private sector (Bağdigen \& Dökmen, 2006).
Public investment expresses the investments made to the physical infrastructure such as roads, bridges, power plants, state buildings and systematic infrastructure such as technology support, research-development and human capital and the capital expenditures the productive usage of which continues for over a year (OECD, 2013). Education gains a significant meaning when it comes to the investment of public investments in the systematic infrastructure.

The social characteristic of the state is to affect the strategy to be adopted for public investments. Public investments the social side of which is ignored incline towards developed regions under free market conditions and thereby display a characteristic which increases the regional inequality (Öztürk, 2006). Public investments and expenditures are the reason which deepens the regional discrepancy because an inclination towards developed regions in contrast to underdeveloped regions occurs in public investments and expenditures (Aktakas, 2006; Tek, 2009).

Human capital, which is an alternative to physical capital in the industrial society, has come to the forefront in the information society and gained importance in the development strategies of the countries. Human capital, which is the personnel infrastructure of the information society, defines the specialized human fundamentally (Özyakışır, 2011). Lifelong education with the methods of open and distance learning in the creation of information society is one of the ways to increase the quality of human capital (Berberoğlu, 2010a).

In the global competition environment, companies can be competitive to the extent to which they are productive in production and marketing. The human capital which cannot fulfill the requirements of competition in the business environment can be laid off, regarded as ineligible because, in the private sector, the main objective of companies is to gain profit not to provide employment. Within the human labor, they employ the one of which skill and productivity are the highest and the cost is the lowest. Considering it is more economic to purchase the available one with regard to the company, they do no avoid discarding the human capital instead of renewing it with training. Socioeconomic results and loss caused by this are a subject to be considered by the states 
which are liable not to leave the education of any of its citizens to coincidence and thereby have established the education system. Thus, the state is obliged to create opportunities for lifelong education and to render them accessible, to prevent its citizens from being deprived of their abilities, drifting apart from economic and social life by taking the equality of opportunity into consideration (Miser, 2002). Lifelong education which will increase the quality of human capital is possible with the open and distance education which develops with each passing day depending on the information and communication technologies.

A socioeconomic growth in any region is an indicator of the human capital growth of that region. The improvement of higher education is closely related to socioeconomic growth and plays a significant role in the development of a country from every aspect. As is known, higher education has a critical value in providing the necessary intellectual human input in order to transform a society living in a country or a region into a knowledge-based and innovation-oriented society. Open and distance learning has a considerable share in higher education in terms of the number of students in Turkey (Berberoğlu, 2010b). Especially Anadolu University, Faculty of Open University has a significant mission at this point.

Nelson and Phelps (1966), Lucas (1988), Becker, Murphy and Tamura (1990), Rebelo (1991), Mulligan and Sala-i-Martin (1993), Barro and Lee (1993) explained the effect of human capital on economic growth with endogenous growth models. They emphasized in these studies that it is possible that human capital, which is as significant as physical capital, can increase with educational investments and, thereby, the economic growth rate can be increased. Kelly (1997) asserted in his study that it would not be correct to say something certain related to the effect of public investments and social expenditures on economic growth but social expenditures have a positive impact on economic growth.

Romer (1986), Lucas (1998) and Barro and Sala-iMartin (1995) argued that the law of diminishing returns does not function in the accumulation of human capital based on knowledge. According to Nelson and Phelps (1996), a country of which human capital has developed can reach a rapid growth by imitating the discoveries made in another country. Lucas (1998) attached human capital investments to formal education and to the investments made in the areas of job training at the workplace. Mulligan and Sala-i-Martin (1993) emphasized that human capital yields more profit when compared to physical capital and that the high-level human capital increases the growth rate when compared to production. Barro and Lee (1992) examined the relation between education and economic growth and, as a result, they revealed that the correlation between the average period of education of adults and growth rate is high.

Akdede and Erdal (2004) measured whether income discrepancies per capita among the geographical regions in Turkey declined with the sigma and beta convergence tests and ascertained that public investments have a positive impact on the convergence of provinces but there is an uncertainty regarding the convergence of the regions. Easterly and Rebelo (1993) argued that public investments made in transportation and communication have a positive effect on growth (Yllmazer et al., 2006).

Access to the national market plays a significant role in the regional economic growth and the reduction of poverty. Developing and underdeveloped regions need to reach the markets of developed regions. Due to that access, both economic growth will accelerate and new economic opportunities will arise for poor regions. This situation is valid especially for agricultural products and other labor-intensive products because those who live below the poverty line are usually centered around these sectors.

The economic activities of countries can be maintained by transporting the products in the form of goods or services to markets as extensive as possible. Differences among regions can occur in terms of the domestic trade volume due to reasons such as physical, human and social conditions in a country, the unbalanced distribution of population, differences in agricultural production or the accumulation of industrial activities in specific regions (Şimşek, 2015). These interregional differences can also have reflections on education.

It is known that the regions close to the national market are more developed in comparison with far regi- 
ons depending on their use of the market advantage. The transportation infrastructure has a considerable effect on the economic performances of regions (Aydemir, 2002; Huavari, 2001). Among the reasons for developmental differences between the western and eastern regions in Turkey are the constraints experienced in the market access originating from the transportation infrastructure (Şimşek, 2015).

The activity-based accessibility measurement expresses the level of relation between the points of departure and arrival within the spatial context of activities. One of the activity-based accessibility measurement types used in urban and regional planning is potential measurement (Şimşek, 2015). Potential measurement is a type of measurement which utilizes its opportunities in terms of population density which the settlements harbor in terms of the national market or employment (Rodrigue, Comtois \& Slack, 2009). Potential accessibility is an approach which addresses the accessibility of settlements in a dynamic way, which, in short, considers the location of a settlement in geographical space with regard to its relations with other settlements (Geurs \& Ritsema Van Eck, 2001). When it comes to potential accessibility, the concept of attractiveness gains importance.
The studies carried out on public investments are usually economical. However, it is not always possible to calculate to what extent benefit has been gained with a public investment. The calculation of benefit and cost upon only economic indicators is possible by disregarding the effects except for the economy (Tek, 2009). The studies which address the indirect, in terms of our subject, social and spatial impacts of public investments are quite limited. Thus, our study carries great importance.

\section{Variables in Our Analysis and Analysis}

Anadolu University maintains it's open and distance learning studies in closing the social, cultural and educational deficit in Turkey with outstanding efforts by using the last, up to date technologies since 1982 . Thus, Anadolu University successfully continues its activities with regard to meeting a significant social need by introducing and spreading higher education to everyone every time and everywhere (Berberoğlu, 2010b).

The dependent and indepentent variables for 2013 which were used in the study, are shown as of 2013

\section{Table 1. Dependent and Independent Variables for 2013}

\begin{tabular}{|l|l|l|l|}
\hline \multicolumn{2}{|l|}{ Dependent Variables } & \multicolumn{2}{|c|}{ Independent Variables } \\
\hline y1 & New Enrollments & A & National Market Accessibility \\
y2 & Additional Placements & & Index in terms of Attractiveness \\
y3 & Vertical Transitions & PI ve PI1 & The Provincial Public Investment \\
y4 & Degree Completions & Index \\
y5 & The Second University Enrolments & & \\
y6 & Enollment Un-Renewals & & \\
y7 & Total & & \\
y8 & Renewal Enrollments & & \\
\hline
\end{tabular}

New Enrollments (y1): The number of students enrolled in the open education system for the first time.

Additional Placements (y2): The number of students enrolled the new departments, the quota stuffed departments or even though the quota is full, the departments which have vacancies because of no certain enrollment.
Vertical Transitions (y3): The number of students that makes vertical transition according to the field of undergraduate graduation who are owning the possibility of direct enrollment.

Degree Completions (y4): The number of students which received only an undergraduate degree from the four-year colleges or high schools, and enroll to 
the fifth semester to complete a faculty education without an examination.

The Second University Enrollments (y5): The number of students which enrolls the undergraduate and graduate programs in the Open Education system as a second university without any examination.

Enrollment Un-Renewals (y6): The number of students which aren't continuing the education in the Open Education system and not making enrollment for a new year.

Total (y7): Total numbers of students

Renewal of Enrollments (y8): The number of students which are continuing the education in the Open Education system and making enrollment for a new year.

The dependent variables presented in Table 1 in order to measure the demand for the Open Education System on the basis of provinces were used in this analysis by the special courtesy of Anadolu University, Deanship of the Faculty of Open Education.

Index of accessibility to the national market in terms of attractiveness (A): Accessibility in terms of attractiveness is defined as the capacity to access one province from other provinces (Rodrigue, Comtois \& Slack, 2009). The accessibility capacity of a province in terms of attractiveness is the total of potential relations of one province with other provinces by using the province-based total population and the road distance among provinces. The province of which accessibility total value in terms of attractiveness is the highest is Istanbul, the lowest is Hakkâri. For instance, the existence of a district hospital in a province or the establishment of a fairground, the coming of service beneficiaries to that province from nearby provinces cause the index value of that province to increase. Therefore, the increase of public and private centers which will offer service to more than one province renders that province to be preferable. Thus, the coming of those who want to get service to that province from nearby provinces increases the accessibility index in terms of attractiveness. The increase of the centers which increase the attractiveness in the province increases, on the other hand, employment and the need for qualified labor. Hence, open and distan- ce education in that province gains great importance.

Public investment index according to provinces (PI and PI1): Public can invest in order to realize the aim in both ways social and economic. However, public investments need to focus on basic infrastructure services such as roads, sewage, energy, education, and health in order to primarily supervise social balances and to meet human needs in especially underdeveloped and developing regions and to bring these services to every corner of the country. After meeting these basic infrastructure needs, public investments are expected to focus on targets such as economic and productivity. Otherwise, in the regions in which basic needs are not met, unrest and disobedience and the beginning of intensive migration from these regions to the regions of which infrastructure is completed, thereby political, social and economic unbalance and instabilities occur. The main objective in underdeveloped and developing regions is not only to observe economic ratios but also to meet the human and social needs. Therefore, Anadolu University Open Education System which brings the service of higher education and lifelong education to every province of Turkey provides a significant contribution to satisfying the human and social needs of the country at the regional and urban level. We can regard the Open Education System of Anadolu University which is a state university as a public investment. However, we estimate that the public investments which contribute to the socio-economic development of a region will positively affect the demand for the Open Education System. Here, a mutual relation can be considered. We address this relation one-way in our study and attempt to reveal how public investments which contribute to the socioeconomic development of a province affect the demand for the Open Education System. Therefore, we derived the public investment index in 2 different ways. One of these is the location index derived with regard to the location average well-known by many academicians and statisticians:

$\mathrm{PI}=($ Provincial public investment $/$ public investment average regarding provinces) $\times 100$

As also well-known by many academicians and statisticians, regression model that involves more than one regressor variable is called a multiple regression model. Such multiple regression model is as below. 


$$
y=\beta_{0}+\beta_{1} x_{1}+\beta_{2} x_{2}+\epsilon
$$

This is a multiple linear regression model with two regressor variables. Such models are generally analized with the ordinary least squares (OLS) method (Draper and Smith, 1998).
In our study, we constructed first multiple linear regression model as;

$$
y=\beta_{0}+\beta_{1} P I+\beta_{2} A
$$

Linear Models created according to the location index of public investment are presented in Table 2:

\begin{tabular}{|c|c|c|c|c|c|}
\hline \multirow[t]{2}{*}{ OLS Models } & Constant & $\begin{array}{l}\text { Public Investment } \\
\text { (PI) }\end{array}$ & $\begin{array}{l}\text { Attractiveness } \\
\text { (A) }\end{array}$ & & \\
\hline & $\begin{array}{l}\beta_{0} \\
\text { (standard error) } \\
\text { t value }\end{array}$ & $\begin{array}{l}\beta_{1} \\
\text { (standard error) } \\
\text { t value }\end{array}$ & $\begin{array}{l}\beta_{2} \\
\text { (standard error) } \\
\text { t value }\end{array}$ & $\operatorname{Adj} . R^{2}$ & $\mathrm{~F}$ \\
\hline \multirow{3}{*}{$\begin{array}{l}\text { New Enrollments } \\
\text { (y1) }\end{array}$} & -2405.812 & 13.803 & 157.144 & \multirow[t]{3}{*}{0.793} & \multirow[t]{3}{*}{154.692} \\
\hline & $(341.900)$ & $(1.446)$ & $(16.710)$ & & \\
\hline & -7.037 & 9.545 & 9.404 & & \\
\hline \multirow{3}{*}{$\begin{array}{l}\text { Additional } \\
\text { Placements } \\
\text { (y2) }\end{array}$} & -451.435 & 2.816 & 30.347 & \multirow[t]{3}{*}{0.797} & \multirow[t]{3}{*}{157.630} \\
\hline & $(67.280)$ & $(0.285)$ & $(3.288)$ & & \\
\hline & -6.710 & 9.894 & 9.229 & & \\
\hline \multirow{3}{*}{$\begin{array}{l}\text { Vertical Transfers } \\
\text { (y3) }\end{array}$} & -2849.640 & 13.423 & 187.963 & \multirow[t]{3}{*}{0.747} & \multirow[t]{3}{*}{119.168} \\
\hline & $(422.842)$ & $(1.789)$ & $(20.666)$ & & \\
\hline & -6.739 & 7.505 & 9.095 & & \\
\hline \multirow{3}{*}{$\begin{array}{l}\text { Degree } \\
\text { Completions (y4) }\end{array}$} & -59.741 & 0.513 & 3.187 & \multirow[t]{3}{*}{0.863} & \multirow[t]{3}{*}{252.446} \\
\hline & $(7.849)$ & $(0.033)$ & $(0.384)$ & & \\
\hline & -7.611 & 15.464 & 8.307 & & \\
\hline \multirow{3}{*}{$\begin{array}{l}\text { The Second } \\
\text { University } \\
\text { Enrollments (y5) }\end{array}$} & -2105.662 & 13.153 & 122.852 & \multirow[t]{3}{*}{0.819} & \multirow[t]{3}{*}{182.342} \\
\hline & (273.957) & $(1.159)$ & (13.389) & & \\
\hline & -7.686 & 11.351 & 9.175 & & \\
\hline \multirow{3}{*}{$\begin{array}{l}\text { Unrenewed } \\
\text { Enrollments (y6) }\end{array}$} & -23913.376 & 109.587 & 1437.439 & \multirow[t]{3}{*}{0.757} & \multirow[t]{3}{*}{125.801} \\
\hline & $(3239.927)$ & (13.704) & (158.349) & & \\
\hline & -7.381 & 7.997 & 9.078 & & \\
\hline \multirow{3}{*}{$\begin{array}{l}\text { Total } \\
\text { (y7) }\end{array}$} & -50043.241 & 242.689 & 3046.736 & \multirow[t]{3}{*}{0.766} & \multirow[t]{3}{*}{132.207} \\
\hline & $(6836.235)$ & $(28.916)$ & $(334.116)$ & & \\
\hline & -7.320 & 8.393 & 9.119 & & \\
\hline \multirow{3}{*}{$\begin{array}{l}\text { Renewal } \\
\text { Enrollments (y8) }\end{array}$} & -18436.386 & 89.983 & 1117.391 & \multirow[t]{3}{*}{0.766} & \multirow[t]{3}{*}{132.184} \\
\hline & $(2520.382)$ & $(10.661)$ & $(123.182)$ & & \\
\hline & -7.315 & 8.441 & 9.071 & & \\
\hline
\end{tabular}

Table 2. Linear Models (PI and A)

In the other one, as in the accessibility index in terms of attractiveness, the objective was to derive an index on the basis of the province with the highest value. Thus, since the province to which the highest public investment has been made is Istanbul, we indexed the index values of public investments by provinces with the following formula:

PI1 $=$ (Provincial public investment $/$ Public invest ment of Istanbul) $\times 100$

In the study, we constructed second multiple linear regression model as;

$$
y=\beta_{0}+\beta_{1} P I 1+\beta_{2} A
$$

The models which we created on the basis of Istanbul are displayed in Table 3. The coefficients of the Constant and Attractiveness index turned out to be the same in Table 2 and Table 3. It only altered the public investment coefficient that we derived the index values by using different formulae of public investment. However, it did not alter the significance and $\mathrm{R}^{2}$ values of the models. 
Table 3. Linear Models (PI1 and A)

\begin{tabular}{|c|c|c|c|c|c|}
\hline \multirow[t]{2}{*}{ OLS Models } & Constant & $\begin{array}{l}\text { Public Investment } \\
\text { (PI1) }\end{array}$ & $\begin{array}{l}\text { Attractiveness } \\
\text { (A) }\end{array}$ & & \\
\hline & $\begin{array}{l}\beta_{0} \\
\text { (standard error) } \\
\text { t value }\end{array}$ & $\begin{array}{l}\beta_{1} \\
\text { (standard error) } \\
\text { t value }\end{array}$ & $\begin{array}{l}\beta_{2} \\
\text { (standard error) } \\
\text { t value }\end{array}$ & Adj. $R^{2}$ & $\mathrm{~F}$ \\
\hline \multirow{3}{*}{$\begin{array}{l}\text { New Enrollments } \\
\text { (y1) }\end{array}$} & -2405.812 & 92.697 & 157.144 & \multirow[t]{3}{*}{0.793} & \multirow[t]{3}{*}{154.692} \\
\hline & $(341.900)$ & $(9.712)$ & $(16.710)$ & & \\
\hline & -7.037 & 9.545 & 9.404 & & \\
\hline \multirow{3}{*}{$\begin{array}{l}\text { Additional } \\
\text { Placements } \\
\text { (y2) }\end{array}$} & -451.435 & 18.910 & 30.347 & \multirow[t]{3}{*}{0.797} & \multirow[t]{3}{*}{157.630} \\
\hline & $(67.280)$ & $(1.911)$ & $(3.288)$ & & \\
\hline & -6.710 & 9.894 & 9.229 & & \\
\hline \multirow{3}{*}{$\begin{array}{l}\text { Vertical Transfers } \\
\text { (y3) }\end{array}$} & -2849.640 & 90.147 & 187.963 & \multirow[t]{3}{*}{0.747} & \multirow[t]{3}{*}{119.168} \\
\hline & $(422.842)$ & $(12.011)$ & $(20.666)$ & & \\
\hline & -6.739 & 7.505 & 9.095 & & \\
\hline \multirow{3}{*}{$\begin{array}{l}\text { Degree } \\
\text { Completions (y4) }\end{array}$} & -59.741 & 3.448 & 3.187 & \multirow[t]{3}{*}{0.863} & \multirow[t]{3}{*}{252.446} \\
\hline & $(7.849)$ & $(0.223)$ & $(0.384)$ & & \\
\hline & -7.611 & 15.464 & 8.307 & & \\
\hline \multirow{3}{*}{$\begin{array}{l}\text { The Second } \\
\text { University } \\
\text { Enrollments (y5) }\end{array}$} & -2105.662 & 88.330 & 122.852 & \multirow[t]{3}{*}{0.819} & \multirow[t]{3}{*}{182.342} \\
\hline & $(273.957)$ & $(7.782)$ & (13.389) & & \\
\hline & -7.686 & 11.351 & 9.175 & & \\
\hline \multirow{3}{*}{$\begin{array}{l}\text { Unrenewed } \\
\text { Enrollments (y6) }\end{array}$} & -23913.376 & 735.948 & 1437.439 & \multirow[t]{3}{*}{0.757} & \multirow[t]{3}{*}{125.801} \\
\hline & $(3239.927)$ & $(92.034)$ & (158.349) & & \\
\hline & -7.381 & 7.997 & 9.078 & & \\
\hline \multirow{3}{*}{$\begin{array}{l}\text { Total } \\
\text { (y7) }\end{array}$} & -50043.241 & 1629.818 & 3046.736 & \multirow[t]{3}{*}{0.766} & \multirow[t]{3}{*}{132.207} \\
\hline & $(6836.235)$ & $(194.190)$ & $(334.116)$ & & \\
\hline & -7.320 & 8.393 & 9.119 & & \\
\hline \multirow{3}{*}{$\begin{array}{l}\text { Renewal } \\
\text { Enrollments (y8) }\end{array}$} & -18436.386 & 604.296 & 1117.391 & \multirow[t]{3}{*}{0.766} & \multirow[t]{3}{*}{132.184} \\
\hline & $(2520.382)$ & (71.594) & $(123.182)$ & & \\
\hline & -7.315 & 8.441 & 9.071 & & \\
\hline
\end{tabular}

\section{Conclusion}

The models which we created on the basis of Istanbul are displayed in Table 3. The coefficients of the Constant and Attractiveness index turned out to be the same in Table 2 and Table 3. It only altered the public investment coefficient that we derived the index values by using different formulae of public investment. However, it did not alter the significance and $\mathrm{R}^{2}$ values of the models.

The most important factor of regional and local development is the socioeconomic performance of a province. Providing resources to provinces, increasing the quality of life of the people living there and maintaining these are among the significant duties of the state. The duty again falls to the state in order for the injustice related to the level of welfare among the provinces and regions to be eliminated. The state fulfills this duty by making public investments (Yllmazer et al., 2006).
Ensuring the balanced development of the provinces located in various geographical regions of our country is possible by pursuing an effective development policy across the country. It was determined in our development plans and in the application of regional development policies that the principles of sustainability, unity among regions, ensuring social and economic balances, improving the quality of life, equality of opportunity, cultural development, and participation would be taken into consideration. Ensuring balanced development requires the use of the current resources at the intended level (Gölbaşı Şimşek \& Noyan, 2008).

It is obvious that accessibility to the national market, which is a part of transportation infrastructure, and public investments have an important role in the solution of the backwardness problem and increasing the attractiveness of a settlement. In the case of the differentiation of public investments and accessibility 
to the national market in terms of attractiveness, differences among provinces can occur depending on the economic growth and increase in welfare.

Accessibility which is regarded as a welfare indicator in developed societies is one of the key factors which affect the development of a settlement. In terms of the regional development, the settlements of which accessibility level in terms of attractiveness is high are seen socioeconomically more developed than less accessible settlements.

The main objective of our study was to present how the accessibility in terms of attractiveness, which affects the interregional socioeconomic development level, which is one of the significant structural problems in our country, and public investments affect the demand for the Open Education System. All the models and coefficients which we produced accordingly turned out to be statistically significant. Furthermore, it is seen that $R^{2}$ values are considerably high. The coefficients of both public investments by provinces and the closeness to the national market in terms of attractiveness turned out to be positive. Accordingly, the more public investments are made to a province and the closer a province is to the national market in terms of attractiveness, the more increase the demand for the Open Education System displays.

\section{References}

Akdede, S. H. ve Erdal, F. (2004). Bölgesel Yakınsamada Kamu Yatırımları: Türkiye Örneği' Kentsel Ekonomik Araştırmalar Sempozyumu, Cilt I, DPTPamukkale Üniversitesi, pp.1-8.

Aktakas, B. G. (2006). Bölgesel/ Yerel Kalkınma, Bölgesel Gelişme İçin Bir Model, Yayınlanmamış Yüksek Lisans Tezi, Çukurova Üniversitesi, Sosyal Bilimler Enstitüsü, p. 87.

Aydemir, Z. C. (2002). Bölgesel Rekabet Edebilirlik Kapsamında İllerin Kaynak Kullanım Görece Verimlilikleri: Veri Zarflama Analizi, Basılmamış DPT Uzmanlık Tezi, Yayın No: 2664.
Bağdigen, M. \& Dökmen, G. (2006). Yolsuzluğun Kamu Gelir ve Giderleri Üzerine Etkisi, Zonguldak Karaelmas Üniversitesi Sosyal Bilimler Dergisi, 2(3), pp. 53-69.

Barro, R. \& Sala-I-Martin, X. (1995). Economic Growth, McGraw-Hill, New York, United States, p.539.

Barro, R.J. \& Lee, J. W. (1993). International Comparisions of Educational Attaiment, Journal of Monetary Economics, 32, pp.363-394.

Becker, G. S., Murphy, K. M. \& Tamura, R. (1990). Human Capital, Fertility, and Economic Growth, Journal of Poitical Economy, 98(5), pp. 12-37.

Berberoğlu, (2010a). Ekonomik Performansin Anadolu Üniversitesi’nde Uzaktan Eğitim Yapan Fakültelerin Mezun Sayılarına Etkisi, Anadolu Üniversitesi Sosyal Bilimler Dergisi, Anadolu University Journal of Social Sciences, Cilt/Vol: 10, Sayı/No: 2, pp. 99110.

Berberoğlu, (2010b). Bilgi Toplumu ve Bilgi Ekonomisi Oluşturma Yolunda Türkiye ve Avrupa Birliği, Marmara Üniversitesi İktisadi ve İdari Bilimler Fakültesi Dergisi Journal of the Faculty of Economic and Administrative Sciences, Y1l/Year: 2010, Cilt/ Volume: XXIX, Sayı/Issue: II, pp.111-131.

Draper, N. R., \& Smith, H. (1998). Applied Regression Analysis, New York: Wiley Series.

Easterly, W. \& Rebelo, S. (1993). Fiscal Policy and Economic Growth: An Emprical Investigation, Journal of Monetary Economics, 32, pp. 417-458.

Geurs, K. T., \& Ritsema van Eck, J. R. (2001). Accessibility Measures: Rewiev and Applicatons, Urban Research Center, Utrecht University.

Gölbaşı Şimşek, G. \& Noyan, F. (2008). İlçelerin Gelişmişlik İndekslerinin Oluşturulmasında Çok Aşamalı Doğrulayıcı Faktör Analizi Yaklaşımı, İstatistikçiler Dergisi, 1, pp. 50-67. 
Huavari, J., Kangasharju A. \& Alanen, A. (2001). Constructing an Index for Regional Competitiveness, Pellervo Economic Research Institute Working $\mathrm{Pa}$ pers, No: 44, Helsinki.

Kalem, A. (2015). Türkiye'deki Kamu Yatırımlarının Özel Sektör Yatırımlarına Etkisinin İncelenmesi, Uzmanlık Tezi, Yatırım Programlama, İzleme ve Değerlendirme Genel Müdürlüğü, Mart, ISBN: 78605-9041-45-4 Yayın No: 2922.

Kelly, T. (1997). Public Expenditures and Growth, The Journal of Development Studies, 34(1), pp. 60-84.

Lucas, R. (1998). On mechanics of Economic Development, Journal of Monetary Economics, 22(1), pp.3-4.

Miser, R. (2002). ‘Küreselleşen’ Dünyada Yetişkin Eğitimi, Ankara Üniversitesi, Eğitim Bilimleri Fakültesi Dergisi, 35(1-2), pp. 55-60.

Mulligan, C. B. \& Sala-i-Marti, X. (1993). Transitional Dynamics in Two SectorModels of Endogenous Growth, Quarterly Journal of Economics, 108(3), pp. 737-773.

Nelson, R. R. \& Phelps, E.S. (1966). Investment in Humans, Technological Diffusion, and Economic Growth, The American Economic Rewiev, 56(1/2), pp.69-75.

Organisation for Economic Co-operation and Development (OECD), (2013). Principles on Effective Public Investment - A Shared Responsibility Across Levels of Government, November.

Öztürk, L. (2006). Geçiş Ekonomilerinde Bölgeler Arası Dengesizlikler: Bir Neden Olarak Piyasa Ekonomisi, Sosyal Bilimler Dergisi, 16, pp. 21-35.
Özyakışır, D. (2011). Beşeri Sermayenin Ekonomik Kalkınma Sürecindeki Rolü: Teorik Bir Değerlendirme, Girişimcilik ve Kalkınma Dergisi, Journal of Entrepreneurship and Development, Vol. 6, (1), pp. 46-71.

Rebelo, S. T. (1991). Long-Run Policy Analysis and Long-Run Growth, Journal of Political Economy, 99(3), pp.500-521.

Rodrigue, J. P., Comtois, C. \& Slack, B. (2009). The Geograph of Transport Systems, New York: Routledge.

Romer, P. (1986). Increasing Returns and LongRun Growth, Journal of Political Economy, 94(5), pp.1003-1037.

Şimşek, A. (2015). Erişilebilir Şehirler ve Bölgeler: Erişilebilirliğin Bölgesel Kalkınmaya Etkisi ve İller Bazında Erişilebilirlik Endeksinin Geliştirilmesi, T. C. Kalkınma Bakanlığı, Bölgesel Gelişme ve Yapısal Uyum Genel Müdürlüğü, Ekim, ISBN: 97-6059041-59-1, Yayın No: 2945.

Tek, M. (2009). 1980 Sonrası Hatay İlinde Kamu Yat1rımları ve Kentleşmeye Etkisi: Nicel Bir Değerlendirme, Mustafa Kemal Üniversitesi Sosyal Bilimler Enstitüsü Dergisi, Mustafa Kemal University Journal of Social Sciences Institute, 6(12), pp. 351-372.

Yılmazer, M., Aktaş, H., Kargın, M. \& Açıkgöz, B. (2006). Türkiye'de İllere Göre Kamu Yatırımlarının Etkinliği, Gazi Üniversitesi, İktisadi ve İdari Bilimler Fakültesi Dergisi, 8(2), pp. 53-80. 